\title{
Elevated Iron Chelating Activity of Ilex paraguariensis Leaf Infusion: in vitro and in vivo Pilot Studies
}

\section{Cristiane Manfé Pagliosa ${ }^{1}$}

https://orcid.org/0000-0002-0553-4621

Francilene Gracieli Kunradi Vieira ${ }^{1 \star}$

https://orcid.org/0000-0003-4211-9133

\section{Taís Thomsen Silveira ${ }^{1}$}

https://orcid.org/ 0000-0001-6919-2467

\author{
Jéssica Ramos Krieguer ${ }^{2}$ \\ https://orcid.org/ 0000-0001-9425-8966 \\ Marcela Freitas Medeiros ${ }^{2}$ \\ https://orcid.org/ 0000-0002-3431-7802 \\ Edson Luiz da Silva ${ }^{1,2}$ \\ https://orcid.org/0000-0002-2602-943X
}

${ }^{1}$ Federal University of Santa Catarina, Health Sciences Center, Nutrition Postgraduate Program, Florianópolis, Santa Catarina, Brazil; ${ }^{2}$ Federal University of Santa Catarina, Health Sciences Center, Department of Clinical Analyses, Florianópolis, Santa Catarina, Brazil.

Editor-in-Chief:Paulo Vitor Farago

Associate Editor:Jane Manfron

Received: 2020.04.07; Accepted: 2020.10.07.

${ }^{*}$ Correspondence: francilene.vieira@ufsc.br; Tel.: +55-48-37218014 (F.G.K.V.).

\section{HIGHLIGHTS}

- Ilex paraguariensis infusion reaches elevated iron chelating potential.

- Storage for $24 \mathrm{~h}$ decreases phenolic acids without affecting iron chelating activity.

- This infusion may be exploited as a natural iron chelating agent.

Abstract: This study presents an Ilex paraguariensis leaf infusion with important potential as natural ironchelating. The impact of infusion time and the water volume to obtain an Ilex paraguariensis leaf infusion with high phenolic content and iron chelating activity, such as the stability of these proprieties in the storage time and temperature (immediately and after $24 \mathrm{~h}$ at 8 and $25^{\circ} \mathrm{C}$ ) were assessed. The acute consumption effect of this infusion to reduce iron absorption in vivo was also evaluated. A preliminary crossover trial with volunteers that ingested a meal containing non-haem iron $(11.4 \mathrm{mg})$ with the treatments: Ilex paraguariensis leaf infusion with the highest phenolic content and iron chelating activity $(200 \mathrm{~mL})$ or control (200 mL water). Blood samples were withdrawn before and 1, 2, 3 and $4 \mathrm{~h}$ after the meal for serum iron measurement. The highest phenolic content $(18.1 \mathrm{mg} / \mathrm{mL})$ and iron chelating activity $(\approx 100 \%)$ were observed for 10 min infusion time using $30 \mathrm{~g}$ leaves $/ 300 \mathrm{~mL}$ water. Storage at 8 or $25^{\circ} \mathrm{C}$ for $24 \mathrm{~h}$ decreased total phenolics and dicaffeoylquinic acids by $23.5 \%$ and $25.5 \%$, respectively $(p<0.05)$, without affecting the iron-chelating activity due to a saturating chelating effect at $3.34 \mathrm{mg} / \mathrm{mL}$ phenolic content. Inhibition of the iron absorption in vivo by infusion was $78 \%$ considering the iron recovery at peak maximum. The in vitro and preliminary in vivo results showed a functional property of the llex paraguariensis leaf infusion that may be useful for adjuvant management of iron overload diseases.

Keywords: Ilex paraguariensis leaf infusion; iron chelating activity; phenolic compounds; in vitro and in vivo studies. 


\section{INTRODUCTION}

South Americans have had the habit of drinking Ilex paraguariensis beverages for hundreds of years, and this habit has been increasing all over the world for the positive health effects these beverages confer [1-3]. The antioxidant, anti-inflammatory, hypoglycemic, and hypocholesterolemic properties of Ilex paraguariensis have been reported in human studies [1-9]. However, the iron chelating activity of Ilex paraguariensis has been less studied [10] and free iron may play a role in the genesis and development of several diseases [11,12]. In this context, phenolic-rich plants with iron chelating activity have been studied as chemopreventive agents against neurodegenerative and heart diseases and for hereditary disorders of iron overload [11-13].

The healthy properties of Ilex paraguariensis infusions have been mainly attributed to the phenolic compounds of the chlorogenic acids family extracted, particularly, from the leaves [1,2], which possess a higher solubility for phenolic compounds extraction in water [14].

The effect of infusion preparation on the extraction of phenolic compounds has been reported for products made with traditional Ilex paraguariensis leaves and stems and that were dried using high temperatures $[15,16]$. Taking into account that high temperatures may lead to increased levels of the toxically polycyclic aromatic hydrocarbons (PHAs), in the present study we used llex paraguariensis leaves that were dried at low temperature to avoid PHAs [17]. Although the stability of phenolic compounds in Ilex paraguariensis leaves and leaf powder has been reported [18,19], the referred stability for Ilex paraguariensis infusions was not found in the literature. In addition, there is a lack of information about the in vitro iron chelating activity of Ilex paraguariensis infusion regarding the preparation method and the stabilities if phenolics and iron chelating after storage at different temperatures, and mainly the potential iron chelating effect in humans. It has been reported that formation of a polyphenol iron complex in the human intestinal tract by some plants/foods, may limit iron absorption and this complexation could be a useful adjuvant in the management of iron overload conditions [20-22].

If on the one hand studies and the control of micronutrients deficiency in the population are essential [23], there is also a need to investigate alternatives to conditions in which the excessive iron in the organism could be a crucial health problem [12,20,22].

Boado and coauthors [24] dissolved $40 \mathrm{mg}$ of iron in a traditional South American beverage with leaves and stems of Ilex paraguariensis ("mate"), and it was ingested by women. The study showed that the complexation of the iron could had been in the beverage "mate", before the intake. In the present study, the aim is to investigate the potential of an Ilex paraguariensis leaf infusion to inhibit iron absorption in humans, based on the serum iron response after ingestion of a meal containing high amount of bioavailable iron.

Considering the interest in an infusion rich in phenolic compounds and with an elevated iron chelating activity, this study presents a preparation method (proportion of Ilex paraguariensis leaves and water, and time infusion) to obtain the highest values of these properties. The stabilities of phenolic compounds and the iron-chelating activity were assessed. A preliminary study of the inhibition of dietary iron absorption by Ilex paraguariensis in healthy subjects was also evaluated.

\section{MATERIAL AND METHODS}

\section{Plant Material}

The Ilex paraguariensis leaves were randomly chosen from thirty mate trees, with certificated organic farming and that had more than 20 years old in Catanduvas, State of Santa Catarina, Southern Brazil $\left(27^{\circ} \mathrm{S}\right.$, $51^{\circ} 40^{\prime} \mathrm{W}$, altitude $925 \mathrm{~m}$ ). The sample was identified and a voucher specimen (accession number: FLOR65601) was deposited at the herbarium of the Botanical Department of the Federal University of Santa Catarina, Brazil.

The Ilex paraguariensis leaves with no stems were dried at $50^{\circ} \mathrm{C}$, without using high temperatures to avoid generating PAHs [17], ground and packed in airtight plastic bags by Matebrás (Brazilian Mate Industry ${ }^{\circledR}$ Ltd., Catanduvas, SC, Brazil). Samples stored at $-18 \pm 2{ }^{\circ} \mathrm{C}$ until required.

\section{Preparation of infusions with llex paraguariensis leaves}

Ilex paraguariensis infusions were prepared at different infusion time (2.5, 5.0, and $10.0 \mathrm{~min})$ and with different water volumes $(50,100$, and $300 \mathrm{~mL})$, respecting the same proportion of leaves/water, i.e., 100 $\mathrm{mg} / \mathrm{mL}: 5 \mathrm{~g} / 50 \mathrm{~mL} ; 10 \mathrm{~g} / 100 \mathrm{~mL}$; and $30 \mathrm{~g} / 300 \mathrm{~mL}$. All infusions were prepared in Becker glasses with equal capacity, in triplicate, with ultrapure water at $80 \pm 1{ }^{\circ} \mathrm{C}$ and filtered using vacuum filtration. After 10 min 
infusion, final temperature was also measured. Soluble solids, total phenolic compounds (TPC), and the iron chelating activity were immediately measured.

For time and temperature stability assays, the infusion with the highest extraction of TPC and iron chelating activity was used. The measurement of TPC, chlorogenic acids (CGAs), and iron chelating activity were performed immediately after preparation (time zero) and after $24 \mathrm{~h}$ storage at 8 or $25^{\circ} \mathrm{C}$. All the reagents used in the assay procedures were of analytical or chromatographic grade. All tests were performed in triplicate.

\section{Determination of soluble solids}

Soluble solids were determined by transferring $1.0 \mathrm{~mL}$ llex paraguariensis infusion into a tared test tube and evaporating to dryness. The residue was finally dried in an oven at $103^{\circ} \mathrm{C}$ up to constant weight [25].

\section{Iron-chelating activity}

The ferrous ion-chelating ability of Ilex paraguariensis infusions was determined by measuring the formation of the $\mathrm{Fe}^{2+}$-ferrozine complex according to the method proposed by Dinis, Madeira, and Almeida [26]. Briefly, $15 \mu \mathrm{L}$ of $2 \mathrm{mM} \mathrm{FeSO}_{4}$ was added to $20 \mu \mathrm{L}$ of the llex paraguariensis infusion and the reaction was initiated by the addition of $15 \mu \mathrm{L}$ ferrozine solution $(5 \mathrm{mM})$. The mixture was left to stand at room temperature for $5 \mathrm{~min}$. The absorbance of the solution was there after measured at $562 \mathrm{~nm}$ (Microplate reader Epoch Biotek Instruments, Inc. Winooski, VT, USA). The percentage of inhibition of the ferrozine-Fe ${ }^{2+}$ complex formation was calculated as [(A0-As)/As] ${ }^{*} 100$, where $A 0$ is the control absorbance and As is the infusion absorbance. The control contained all reagents except the llex paraguariensis infusion. The standard metal chelator agent used in this assay was $200 \mathrm{mg} / \mathrm{mL} \mathrm{Na}{ }_{2} E D T A$.

\section{Total phenolic content quantification}

The TPC of the Ilex paraguariensis infusions was determined according to the Folin-Ciocalteu procedure [27] with a UV-Vis spectrophotometer (Shanghai spectrum instruments Co., model SP-2000UV Shanghai Spectrum, Shanghai, China). An infusion aliquot $(1 \mathrm{~mL})$ was diluted to $50 \mathrm{~mL}$ of ultrapure water. An external calibration curve with chlorogenic acid (Sigma-Aldrich, St. Louis, MO) at concentrations between 7.8 and 500 $\mu \mathrm{g} / \mathrm{mL}$ was used $\left(r^{2}=0.99\right)$. TPC was expressed in $\mathrm{mg}$ of chlorogenic acid equivalents (CAE) per $\mathrm{mL}$ of infusion.

\section{Identification and quantification of phenolic compounds}

The chromatographic analysis was performed in a Shimadzu LC-10 high-performance liquid chromatography (HPLC) system, equipped with a reverse-phase column (Shim-pack $\mathrm{C}_{18}, 4.6 \mathrm{~mm} \varnothing \times 250$ $\mathrm{mm}$ ), guard column (Phenomenex $\mathrm{C}_{18} 4 \mathrm{~mm} \varnothing \times 2 \mathrm{~mm}, 5 \mu \mathrm{m}$ ) and an UV-Vis detector (Shimadzu SPD 10A, Shimadzu, Kyoto, Japan) set at $325 \mathrm{~nm}$.

Ilex paraguariensis infusion was centrifuged $\left(1.000 \times \mathrm{g}, 10 \mathrm{~min}, 25^{\circ} \mathrm{C}\right)$, filtered in $0.45 \mu \mathrm{m}$ membranes (Merck Millipore, USA) and $20 \mu \mathrm{L}$ were injected into the column. The chromatographic conditions for the gradient were described by Farah, De Paulis, Trugo, and Martins [28], and modified by Alves, 2016 [29] as follows: Eluent $\mathrm{A}: 80 \% 10 \mathrm{mM}$ citric acid solution, $\mathrm{pH} 2.5$, adjusted with $6 \mathrm{~N}$ hydrochloric acid, and $20 \%$ methanol. Eluent B: methanol. Gradient: Eluent A, 100\% to $80 \%$ during $15 \mathrm{~min} ; 80 \%$ during $10 \mathrm{~min}$ additional and; $80 \%$ to $100 \%$ for $5 \mathrm{~min}$. The flow rate was $1 \mathrm{~mL} / \mathrm{min}$ and run time $30 \mathrm{~min}$.

The identification of phenolic acids was carried out by comparing the retention time and absorption spectra of Ilex paraguariensis infusion peaks with standard compounds. The quantification of the CGAs was based on calibration curves $\left(r^{2}=0.99\right)$ of each identified compound in the infusion. The standard compounds 3-caffeoylquinic acid (3-CQA) ( $\geq 98 \%$ ), 4-caffeoylquinic acid (4-CQA) ( $\geq 98 \%$ ), 5-caffeoylquinic acid (5-CQA) ( $\geq 98 \%)$, 3,5-di-caffeoylquinic acid (3,5-di-CQA) $(\geq 95 \%)$, and 4,5-di-caffeoylquinic acid (4,5-di-CQA) $(\geq 85 \%)$ were purchased from Sigma-Aldrich (St. Louis, MO). Mean and standard deviation $(n=3)$ were calculated.

An in silico analysis carried out using the software Prediction of Activity Spectra for Substances (PassOnline) (http://www.pharmaexpert.ru/passonline) [30] was used to assess whether the 3-, 4-, 5-, 3,5-, or 4,5-caffeoylquinic acids could be candidates to complex with iron. 


\section{Subjects and study design}

The iron absorption was measured based on the serum iron response after ingestion of a meal containing a high amount of bioavailable iron (11.4 $\mathrm{mg}$, as described below). This preliminary controlled, randomized, and crossover trial was carried out with three healthy subjects (two male, aged 26 and 38 y-old; and one female, $26 \mathrm{y}$-old). The inclusion criteria were adults with no clinical diseases, including the presence of acute or chronic infection, iron overload disease or anemia, no history of gastrointestinal illness, body mass index $(\mathrm{BMI})<30 \mathrm{~kg} / \mathrm{m}^{2}$, non-alcoholic, no use of medicines or dietary supplements, and with haematological and serum biochemical routine laboratory results within the normal ranges, including haemoglobin, serum iron and ferritin, C-reactive protein, and liver enzymes. Women in their menstrual phase of the cycle were excluded from this study. Written informed consent was obtained for all persons prior their inclusion in the study, according to the Declaration of Helsinki and the study was approved by the Federal University of Santa Catarina Ethics Committee (CAAE: 64252017.2.0000.0121).

All subjects were instructed to maintain their habitual diet and physical activity and not to intake alcoholic beverages, beverages with Ilex paraguariensis, teas and coffee $24 \mathrm{~h}$ before each study day. Compliance for dietary instructions was carried out through a $24 \mathrm{~h}$ dietary recall. The subjects were requested not to practice any physical activity in the morning of the study.

In a cross-over design, after a fasting overnight, the subjects randomly ingested a meal containing 11.4 $\mathrm{mg}$ non-haem iron and either $200 \mathrm{~mL}$ water (control) or llex paraguariensis leaf infusion (30 g leaves/300 mL water, containing $18.1 \mathrm{mg} / \mathrm{mL}$ TPC). A washout period of one week was used between each control and llex paraguariensis infusion. Sample blood was obtained immediately before and at 1, 2, 3 and $4 \mathrm{~h}$ after the ingestion of the meal and beverages.

\section{Test meal}

The test meal consisted of a mashed potato $(300 \mathrm{~g})$ containing $391 \mathrm{kcal}$ energy; calcium $9.08 \mathrm{mg}$ and $11.4 \mathrm{mg}$ of non-haem iron (1.4 mg endogenous iron plus $10 \mathrm{mg}$ as $\mathrm{FeSO}_{4}$ ). The total iron content was determined in triplicate according to method 944.02a [31]. The Ilex paraguariensis infusion was prepared and immediately served to subjects. For the study, only glass and disposable plastic utensils were used.

\section{Biochemical and hematological analysis}

Blood samples were drawn by vein puncture with vacuum system (Vacutainer, BD, São Paulo, SP, Brazil) into tubes with or without ethylene-diamine-tetra-acetic acid (EDTA), for the baseline analysis. For the serum iron measurement, blood was collected in tubes containing clot activator without EDTA. Serum and plasma were obtained by centrifugation $\left(1000 \times \mathrm{g}, 10 \mathrm{~min}\right.$, at $\left.4^{\circ} \mathrm{C}\right)$ and the samples were analyzed in automated equipment (Dimension RXL Max Siemens Healthcare Diagnostics Inc. Deerfield, IL, USA, and Sysmex XE-2100D Kobe, Japan). For the iron absorption analysis, the parameters derived from the serum iron curves, area under the serum curve (AUC) calculated using the trapezoidal method, the maximum increase in serum iron concentration ( $\triangle$ iron max), and the percentage iron recovery at maximum peak, were used. The $\mathrm{AUC}_{0-4 \mathrm{~h}}$ was calculated in GraphPad Prism v. 6.01 (GraphPad, La Jolla, CA, USA).

\section{Statistical analysis}

Data are expressed as mean \pm standard deviation or as mean \pm standard error of mean. The one-way analysis of variance (ANOVA) or the repeated measure-ANOVA and Tukey post-hoc test were used for differences detection. Association between TPC and iron chelating activity was evaluated using simple linear regression analysis. All statistical analyses were performed at the significance level of $p<0.05$ using SPSS 17.0 (SPSS Inc., Chicago, IL, USA).

\section{RESULTS}

\section{Infusion time and its effect on the extraction of total soluble solids, TPC, and iron chelating activity of Ilex paraguariensis leaves}

Our results revealed a significant improvement of total soluble solids $(p<0.02)$ and TPC $(p<0.001)$ at 10 min infusion time for llex paraguariensis leaves in comparison with 2.5 and 5.0 min (Table 1). 
Table 1. Infusion time and its effects on the extraction of total soluble solids, total phenolic compounds and iron chelating activity of Ilex paraguariensis leaves.

\begin{tabular}{llll}
\hline $\begin{array}{l}\text { Infusion time } \\
(\mathbf{m i n})\end{array}$ & $\begin{array}{l}\text { Total soluble solids } \\
(\mathbf{m g} / \mathbf{m L})^{*}\end{array}$ & $\begin{array}{l}\text { Total phenolic } \\
(\mathbf{m g ~ C A E} / \mathbf{m L})^{\star \star}\end{array}$ & $\begin{array}{l}\text { Iron chelating } \\
(\%)^{\star \star \star}\end{array}$ \\
\hline 2.5 & $19.53 \pm 0.94^{a}$ & $5.40 \pm 0.58^{a}$ & $94.37 \pm 1.55^{a}$ \\
5.0 & $23.56 \pm 0.98^{b}$ & $7.03 \pm 0.65^{a}$ & $97.17 \pm 2.24^{a b}$ \\
10.0 & $29.24 \pm 1.80^{c}$ & $18.48 \pm 2.52^{b}$ & $99.06 \pm 1.70^{b}$ \\
Positive Control $\left(200 \mathrm{mg} / \mathrm{mL} \mathrm{Na}_{2}\right.$ EDTA) & & --- & $99.55 \pm 0.20^{b}$ \\
\hline
\end{tabular}

Results are expressed as mean \pm standard deviation of three determinations in triplicate. Mean values in the same column followed by different lower-case letters are significantly different ${ }^{*}(p<0.02) ;{ }^{* *}(p<0.0001) ;{ }^{* * *}(p<0.05)$; ANOVA and post-hoc Tukey's test. Ultrapure water at $80 \pm 1^{\circ} \mathrm{C}(100 \mathrm{~mL})$ was added to $10 \mathrm{~g}$ leaves of llex paraguariensis.

$\mathrm{CAE}$, chlorogenic acid equivalent.

The llex paraguariensis leaf infusion prepared at 2.5 min infusion time had $94 \%$ iron-chelating capacity and with a significantly higher iron-chelating activity at $10 \mathrm{~min}$ extraction $(>99 \% ; p<0.05)$ (Table 1). This result of iron-chelating close to $100 \%$ was comparable to the positive standard control $\mathrm{Na}_{2} \mathrm{EDTA}$ $(99.5 \%)$ (Table 1). Therefore, 10 min infusion time was chosen for further infusion preparations and assays.

\section{Effect of water volume on the extraction of TPC of Ilex paraguariensis leaf infusions}

Although all the infusions were prepared with the same proportion of leaves/water $(100 \mathrm{mg} / \mathrm{mL})$ and initial water temperature $\left(80^{\circ} \mathrm{C}\right)$ during 10 min infusion, TPC was significantly higher for the water volume of 300 $\mathrm{mL}$ in comparison to $50 \mathrm{~mL}(\mathrm{p}<0.002)$ and $100 \mathrm{~mL}(p<0.0001)$. In addition, a significantly higher final temperature of $63.2 \pm 1.0^{\circ} \mathrm{C}$ was observed for the $300 \mathrm{~mL}$ volume infusion after $10 \mathrm{~min}(p<0.0001)$ (Figure 1).

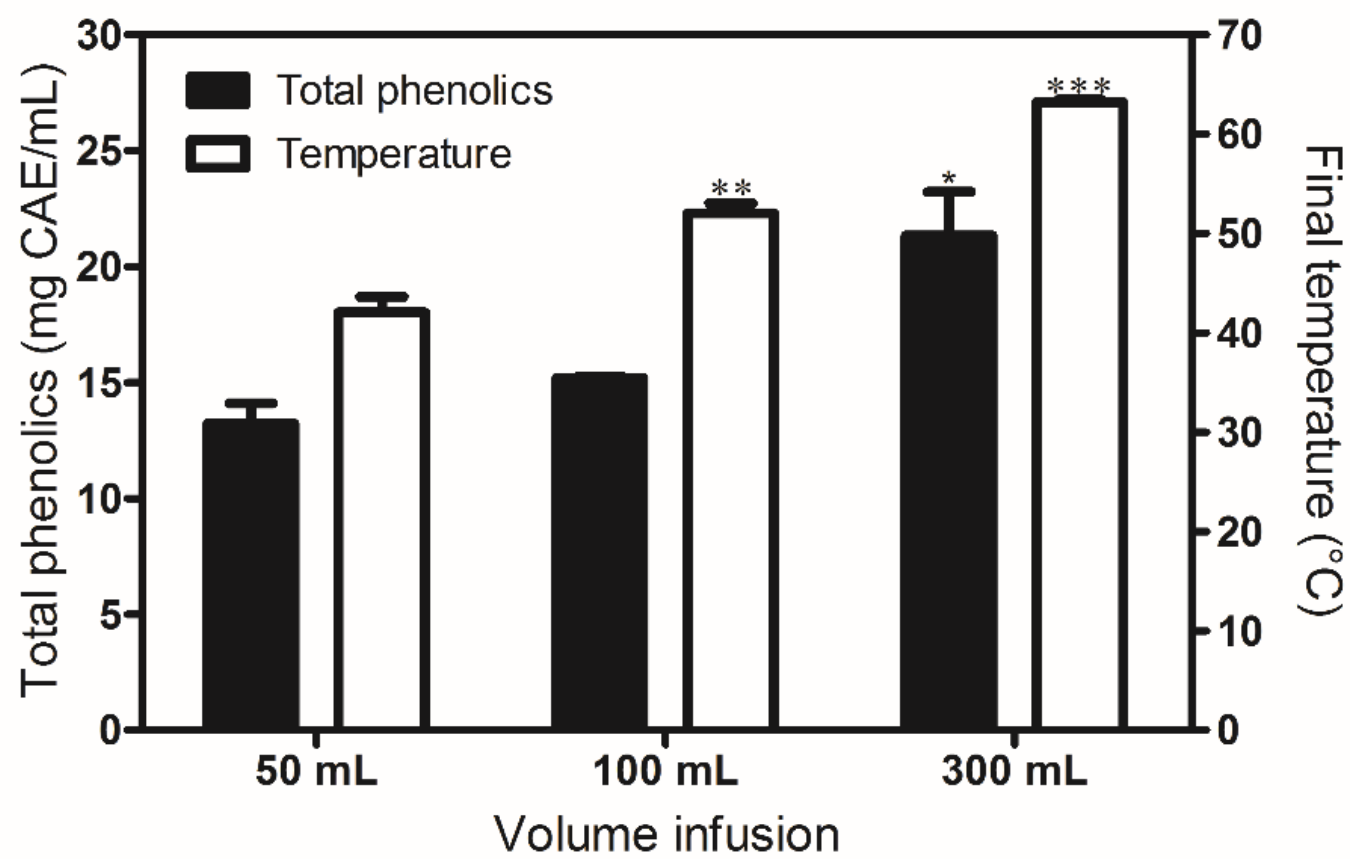

Figure 1. The effect of water volume on the extraction of total phenolic compounds of llex paraguariensis leaf infusions. The extractions were prepared at the same proportion w/v $(100 \mathrm{mg} / \mathrm{mL}): 5 \mathrm{~g} / 50 \mathrm{~mL} ; 10 \mathrm{~g} / 100 \mathrm{~mL}$; and $30 \mathrm{~g} / 300 \mathrm{~mL}$. The initial temperature for all infusions was $80 \pm 1{ }^{\circ} \mathrm{C}$. Results are expressed as mean \pm standard deviation of three determinations in triplicate. ${ }^{* *} p<0.002$ compared to $50 \mathrm{~mL},{ }^{* * * * *} p<0.0001$ compared to 50 - and $100 \mathrm{~mL}$ volumes (ANOVA followed by Tukey test). CAE, chlorogenic acid equivalent.

\section{Stability of total phenolic content and the iron-chelating activity}

After $24 \mathrm{~h}$ storage, a significant decrease in the TPC of Ilex paraguariensis infusion was observed, regardless of temperature, $22.5 \%$ at $8{ }^{\circ} \mathrm{C}$ and $24.5 \%$ at $25^{\circ} \mathrm{C} ; p<0.05$ compared to control (Table 2 ). 
Table 2. Stability of total phenolic content and the iron-chelating activity of Ilex paraguariensis leaf infusion

\begin{tabular}{|c|c|c|}
\hline Time (h) & Total Phenolic $(\mathrm{mg} / \mathrm{mL})$ & Iron chelating (\% \\
\hline Zero (control) & $18.11 \pm 0.27^{a}$ & $99.38 \pm 1.78^{a}$ \\
\hline After $24 \mathrm{~h}\left(8^{\circ} \mathrm{O}\right)$ & $14.04 \pm 0.52^{b}$ & $99.12 \pm 1.53^{a}$ \\
\hline After $24 \mathrm{~h}\left(25^{\circ} \mathrm{C}\right)$ & $13.68 \pm 0.89 b$ & $100.00 \pm 0.00^{a}$ \\
\hline
\end{tabular}

Results are expressed as mean \pm standard deviation of three determinations in triplicate. Mean values in the same column followed by different superscript letters are significantly different $(p<0.05)$. (Repeated measure-ANOVA followed by Tukey test).Ultrapure water at $80 \pm 1^{\circ} \mathrm{C}(300 \mathrm{~mL})$ was added to $30 \mathrm{~g}$ of Ilex paraguariensis leaves.

The present data also indicated a decrease of up to $24.5 \%$ (from 18.1 to $13.7 \mathrm{mg} / \mathrm{mL}$ ) of total phenols in the Ilex paraguariensis leaf infusions, but that did not reflect any change in the iron chelating activity (Table 2). Figure 2a shows a saturating effect of the Ilex paraguariensis phenolic compounds on the iron chelating activity starting from a certain concentration of TPC $(3.34 \mathrm{mg} / \mathrm{mL})$, and the linear regression analysis revealed a significant association between TPC and the iron chelating activity $\left(r^{2}=0.87 ; p<0.01\right)$ for Ilex paraguariensis infusions containing up to $3.34 \mathrm{mg} \mathrm{CAE} / \mathrm{mL}$ TPC (Figure $2 \mathrm{~b} ; \mathrm{y}=16.83 \mathrm{x}+21.68$ ).
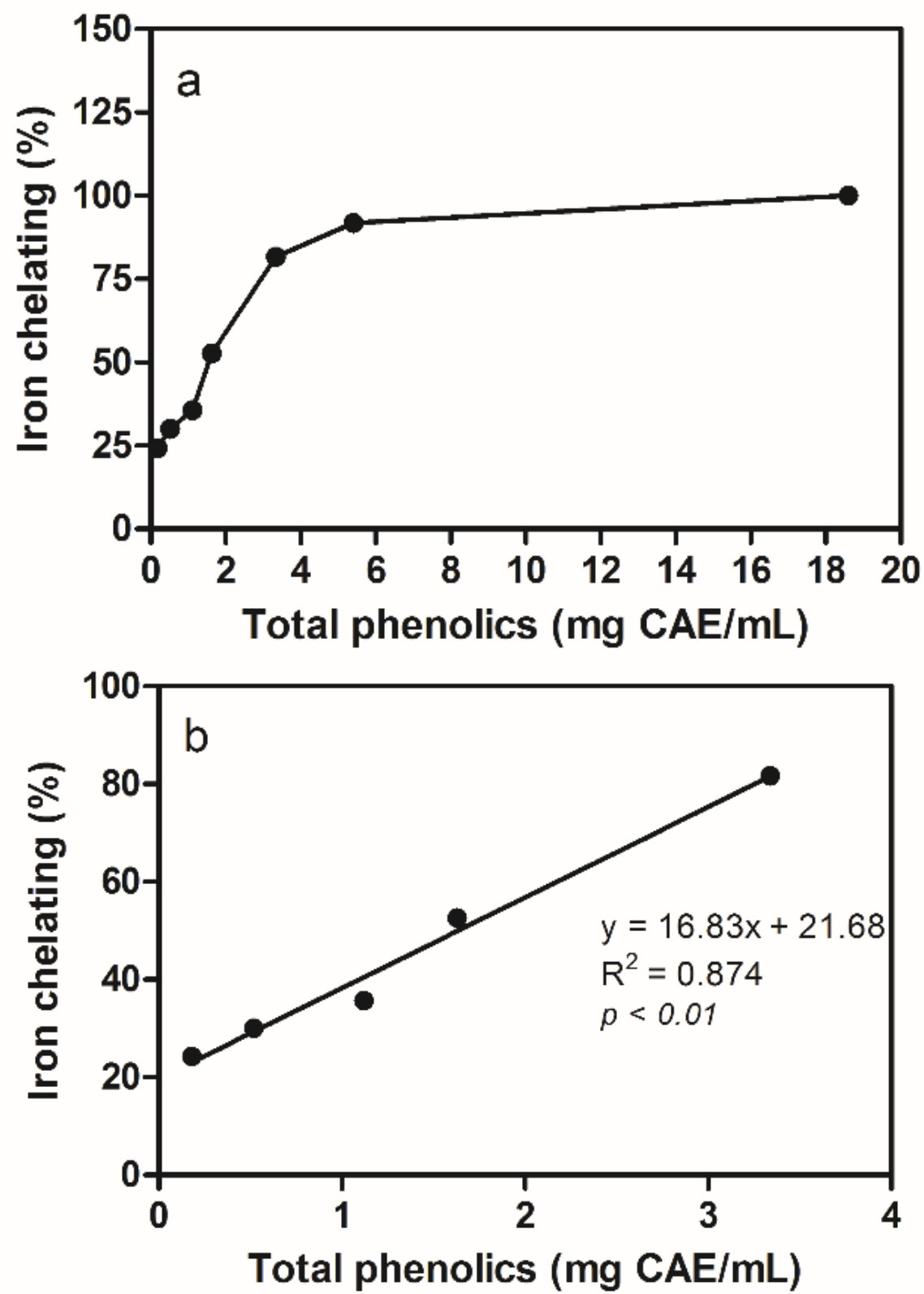

Figure 2. Association (a) and linear regression (b) between total phenolic content (mg CAE/mL) and the iron chelating activity (\%) of Ilex paraguariensis leaf infusions. Results are expressed as mean of three determinations in triplicate. Infusions were prepared at $2.5-100 \mathrm{mg} / \mathrm{mL}$ proportions of leaves/water. CAE, chlorogenic acid equivalent. 


\section{Content and stability of chlorogenic acids of Ilex paraguariensis leaf infusions}

Chlorogenic acids were identified and quantified in the llex paraguariensis infusion with the greatest TPC $(18.1 \mathrm{mg} / \mathrm{mL}$ ) and iron chelating activity (99.4\%) (i.e., $30 \mathrm{~g}$ of leaves per $300 \mathrm{~mL}$ of water at 10 min extraction). The 3-caffeoylquinic acid was present in the highest content $(9.99 \pm 0.66 \mathrm{mg} / \mathrm{mL})$ followed by the 3,5-dicaffeoylquinic acid $(5.64 \pm 0.26 \mathrm{mg} / \mathrm{mL})(p<0.002)$. 5 -Caffeoylquinic $(2.17 \pm 0.27 \mathrm{mg} / \mathrm{mL})$, 4-caffeoylquinic $(2.45 \pm 0.3 \mathrm{mg} / \mathrm{mL})$, and 4,5-di-caffeoylquinic acids $(1.74 \pm 0.19 \mathrm{mg} / \mathrm{mL})$ showed similar contents.

Results of the stability of chlorogenic acids present in the Ilex paraguariensis leaf infusion concerning time and temperature are provided in Figure 3. The three mono-caffeoylquinic acids (3-CQA, 4-CQA, and 5$\mathrm{CQA}$ ) were stable at $8{ }^{\circ} \mathrm{C}$ for an analysed period of $24 \mathrm{~h}$. However, in comparison to time zero, at $25^{\circ} \mathrm{C}$ all mono-caffeoylquinic acids showed significant decrease by $16.0-25.2 \%$ after $24 \mathrm{~h}(p<0.05)$. Furthermore, significant reductions were also observed for 3,5-diCQA (21.9-30.6\%) and 4,5-diCQA (21.6-27.9\%) after 24 $\mathrm{h}$ at 8 or $25^{\circ} \mathrm{C}(p \leq 0.01)$. After $24 \mathrm{~h}$, there were no significant differences between 8 and $25^{\circ} \mathrm{C}$ for all monocaffeoylquinic acids and di-caffeoylquinic acids declines.

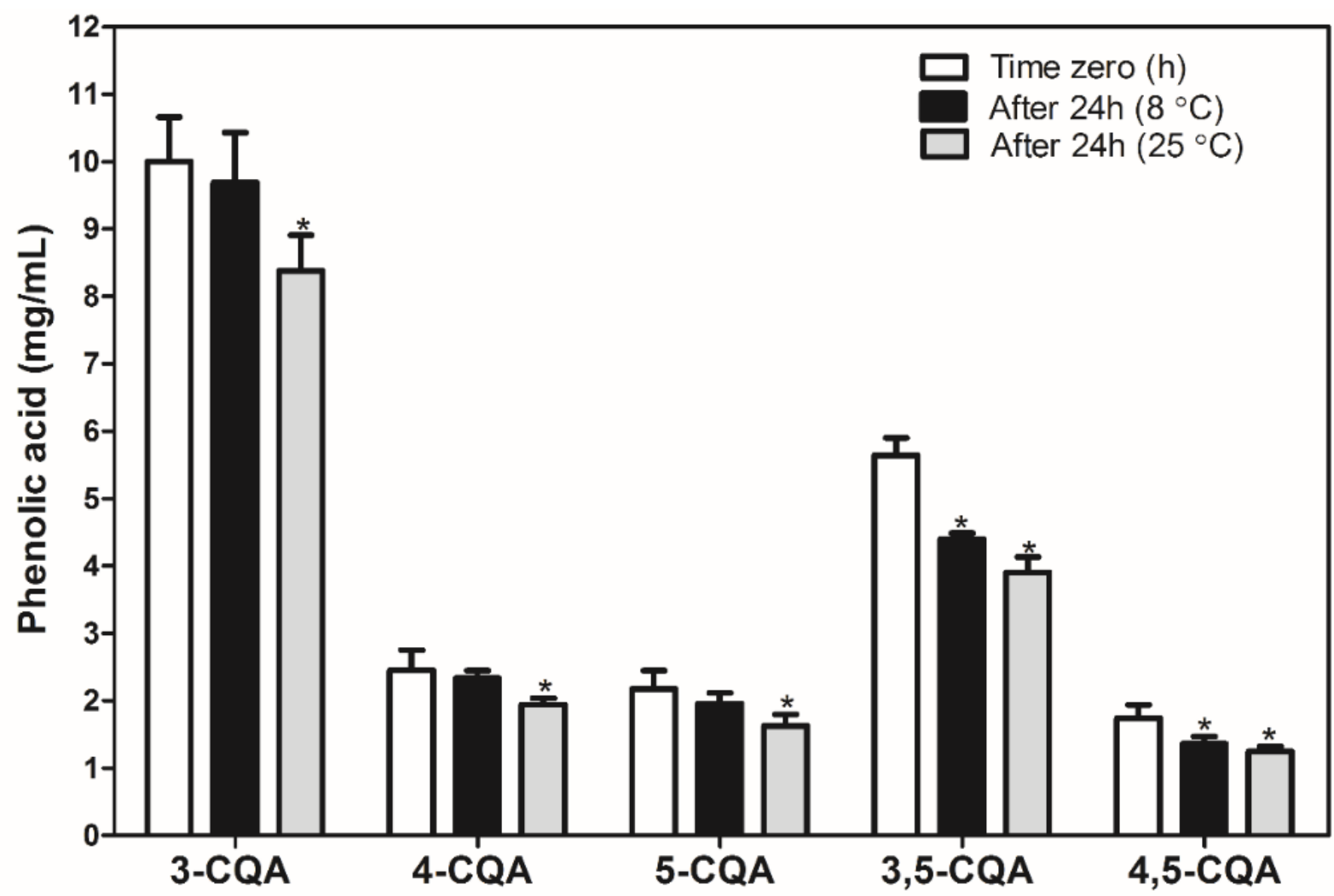

Figure 3. Stability of mono-caffeoylquinic acids (3-CQA, 4-CQA, and 5-CQA) and di-caffeoylquinic acids (3,5-diCQA and 4,5-diCQA) of Ilex paraguariensis leaf infusion. Results are expressed as mean \pm standard deviation of three determinations in triplicate. ${ }^{*} p<0.05$ compared to time zero (RM-ANOVA and Tukey's test). There were no differences between $8{ }^{\circ} \mathrm{C}$ and $25^{\circ} \mathrm{C}$. Ultrapure water at $80 \pm 1{ }^{\circ} \mathrm{C}(300 \mathrm{~mL})$ was added to $30 \mathrm{~g}$ leaves of Ilex paraguariensis.

\section{Effect of Ilex paraguariensis infusion on iron absorption in humans}

The intake of a test meal enriched with iron promoted an expressive increase in the levels of serum iron up to $4 \mathrm{~h}$. Intake of the meal with Ilex paraguarienis infusion showed a substantial reduction in the dietary iron absorption in comparison to water (control) (Figure 4). Based on the parameters derived from the serum iron curves, the llex paraguariensis infusion inhibited the iron absorption by approx. $80 \%$, in average (Table $3)$. 


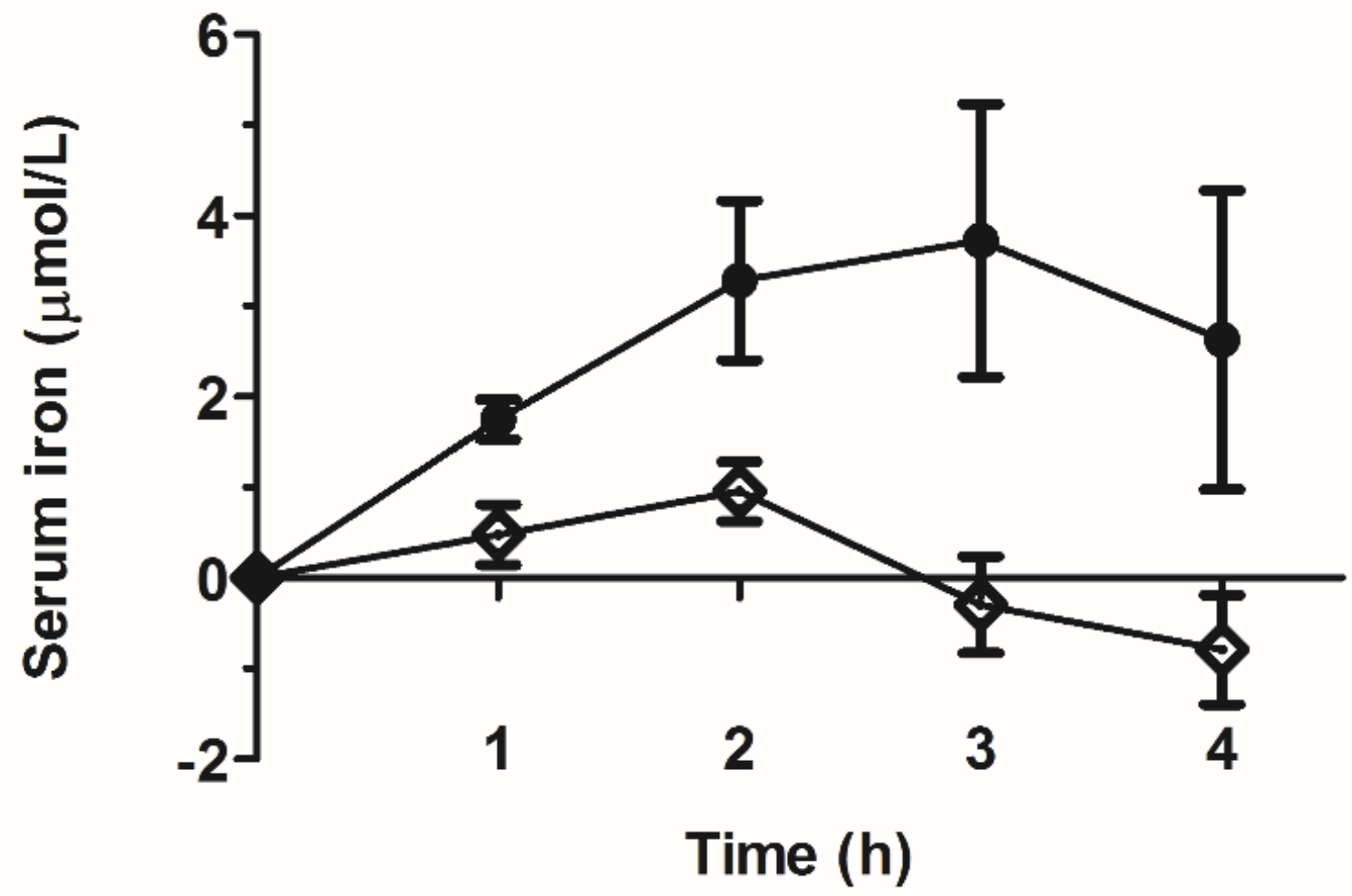

Figure 4. Serum iron curves in healthy subjects $(n=03)$, after ingestion of a single meal containing 11.4 mg non-haem iron (1.4 mg endogenous and $10 \mathrm{mg}$ added as ferrous iron). Values are means $\pm \mathrm{SEM}$. $\bullet$ Water; $\diamond$ Ilex paraguariensis leaf infusion. Ilex paraguariensis infusion prepared at $30 \mathrm{~g}$ leaves $/ 300 \mathrm{~mL}$ water containing $18.1 \mathrm{mg} / \mathrm{mL}$ of total phenols.

Table 3. Parameters derived from serum iron curves and used as indicators of iron absorption in healthy subjects.

\begin{tabular}{lccc}
\hline Parameters & Water (control) & llex paraguariensis infusion ${ }^{\dagger}$ & Inhibition (\%) \\
\hline $\mathrm{AUC}_{0-4 \mathrm{~h}}\left(\mu \mathrm{mol} . \mathrm{min}^{-1} . \mathrm{L}^{-1}\right)$ & $608.9 \pm 194.4$ & $118.4 \pm 51.8$ & 80.5 \\
$\Delta$ iron max. $(\mu \mathrm{mol} / \mathrm{L})$ & $3.84 \pm 0.75$ & $0.78 \pm 0.24$ & 79.7 \\
Iron recovery $(\%$ at peak max.) & $5.13 \pm 0.87$ & $1.11 \pm 0.37$ & 78.4 \\
\hline
\end{tabular}

Values are expressed as mean \pm SEM $(n=3)$. ${ }^{\dagger}$ Prepared with $30 \mathrm{~g}$ leaves $/ 300 \mathrm{~mL}$ water, which contain $18.1 \mathrm{mg} / \mathrm{mL}$ of total phenols. $\mathrm{AUC}_{0-4 h}$ : Area under the curve; $\Delta$ iron max.: Maximum increase in serum iron. Statistical tests were not applied due to the small sample size.

\section{DISCUSSION}

Herbal infusions are typically consumed after contact time herb/hot water during 10 min or less [3,32]. Our results suggested that a better solubility of phenolic compounds of Ilex paraguariensis infusion depends on a longer contact time of leaves with water, in agreement with previous data reported for toasted mate tea [15] and for traditional beverage with Ilex paraguariensis ("chimarrão" or "mate") prepared with minced commercial leaves and stems [16].

Regarding the iron-chelating activity, the present study showed a high value (Table 1) for this plant. A similar result was reported by Colpo and coauthors [10] in a study where the iron chelating activity of Ilex paraguariensis aqueous extract, prepared in the same way as that of the traditional "mate" consumed in South America, was approximately $80 \%$. In relation to the effect of the water volume over the extraction of the phenolic compounds during the preparation of the infusion of Ilex paraguariensis leaves (Figure 1), our finding gives rise to the hypothesis that a higher volume of hot water improved TPC extraction as result of a slower cooling during infusion time. A similar effect was described for Camellia sinensis tea [32].

Altogether, our results confirmed the higher solubility of the phenolic compounds from Ilex paraguariensis in hot water [16]. However, in spite of the increased amount of phenolic content extracted at high temperature, it should be noted that consumption of very hot $\left(>65^{\circ} \mathrm{C}\right)$ beverages such as tea, coffee, and Ilex paraguariensis may increase the risk of esophageal cancer [33]. Therefore, the present results showed a method of preparing Ilex paraguariensis leaf infusions that can be used by consumers with the highest levels of TPC and iron chelating activity with an immediately final safe temperature of $63.2^{\circ} \mathrm{C}$, i.e., 10 min infusion time and water volume of $300 \mathrm{~mL}$ with an initial temperature of $80^{\circ} \mathrm{C}$. 
In order to verify the preservation of the properties investigated in this study, the stability of the phenolic compounds and the iron-chelating activity were evaluated after 24 hours at room temperature and under refrigeration. Studies in plants with abundant phenolic acids, such as coffee [34] and powdered sweet potato dissolved in water [35] reported that oxygen was the most important factor for TPC losses, and temperature can also play a role. According to our results, the storage time of $24 \mathrm{~h}$ affected TPC stability to a greater extent than the temperature did.

The ability to chelating iron ions has been attributed to phenolic compounds such as chlorogenic acids $[36,37]$. The stability of chelating activity against iron in the infusion (Table 2) can be explained by a saturating effect of the llex paraguariensis phenolic compounds on the iron-chelating activity observed at a relatively low amount of TPC (Figure 2a). On the other hand, the linear regression analysis showed a significant association between TPC and the iron chelating activity for llex paraguariensis infusions containing up to $3.34 \mathrm{mg} \mathrm{CAE} / \mathrm{mL}$ TPC (Figure $2 \mathrm{~b}$ ), indicating that most of the iron-chelating activity could be explained by the phenolic compounds effect. Based on these results, we can explain the absence of an association between TPC and the iron-chelating activity of Ilex paraguariensis extracts reported by Colpo and coauthors [10] taking into account that the authors used extracts with higher amounts of total phenolic compounds.

As for the chlorogenic acids detected and their concentration, the results obtained are in agreement with what is reported in the literature for Ilex paraguariensis. [1,14,16,38].

The present study showed the instability of the majority of phenolic acids in Ilex paraguariensis infusion, e.g., the mono-caffeoylquinic and the di-caffeoylquinic acids after $24 \mathrm{~h}$ at $25^{\circ} \mathrm{C}$. These findings are coherent with the results for TPC stability (Table 2), which was measured using a colorimetric assay. Takenaka and coauthors [35] also showed that the CGAs (mono- and di-caffeoylquinic acids) content of powdered sweet potato dissolved in water had decreased after $1 \mathrm{~h}$ at room temperature.

The losses found in CGAs after $24 \mathrm{~h}$ at $25{ }^{\circ} \mathrm{C}$ indicated that Ilex paraguariensis infusions were more sensitive at room temperature and, for this reason, this infusion should be consumed as soon as possible after preparation, or stored in a refrigerator $\left(8^{\circ} \mathrm{C}\right)$ to preserve part of the CGAs (Figure 3). However, for ironchelating purposes, e.g., iron overload diseases, and based on our in vitro results, it seems irrelevant the temperature for consumption of llex paraguariensis infusions, whether refrigerated or at room temperature within $24 \mathrm{~h}$.

An in silico analysis carried out using the software PassOnline showed that the 3-, 4-, 5-, 3,5-, and 4,5caffeoylquinic acids are strong candidates to complex with iron (data not shown). In general, phenolic acids of the chlorogenic acid family have an antioxidant effect due in part to their iron-chelating properties $[36,39,40]$. Indeed, the complexation of iron with caffeoylquinic acids has been considered as an antioxidant mechanism, since complexed iron does not have the ability to promote the generation of reactive oxygen species (ROS), such as hydroxyl radical $\left({ }^{\circ} \mathrm{OH}\right)$ formed in the Fenton reaction [12,36,40]. Evaluating the iron chelation abilities, Andjelković and coauthors [39] showed that hydroxycinnamic acids, such as the CGAs, have higher complex formation capability than hydroxybenzoic acids (gallic and protocathechuic acids).

There are references in the literature about the iron-chelating property of mono-caffeoylquinic acids and di-caffeoylquinic acids, involving studies conducted with UV-visible spectroscopy, electron spin resonance (ESR) spectroscopy, and nuclear magnetic resonance (NMR) spectroscopy. This property has been attributed to (1) a more complex structure in comparison with other phenolic acids (such as the hydroxybenzoic acid derivatives), which involves caffeic acid linked to quinic acid; (2) the ethylene group present in the structures of caffeoylquinic acids, which affects favorably their capacity to be a metal chelator, and (3) the presence of hydroxyl groups, with electron-donating abilities $[36,39,40]$. The quantity and position of hydroxyl groups affect the iron-chelating activity of these phenolic acids. Dihydroxy groups linked with an aromatic ring in the ortho position, referred to as catechol group, improve iron-chelating activity [39]. The caffeoylquinic acids in the Ilex paraguariensis leaf infusion contain dihydroxy groups that have these characteristics and are the binding site of iron in the molecules (Figure 5). Phenolic acids without any catechol groups for hydroxycinnamic acids derivatives or without any galloyl groups for hydroxybenzoic acid derivatives have not shown any complexation with iron [39]. Furthermore, the 4,5-caffeoylquinic acid is an adjacent di-caffeoylquinic acid. Di-caffeoylquinic acids that contain caffeoyl moieties in adjacent position show a more effective iron chelating activity. These acids have more ability to encircle the iron from the chelation reaction in comparison with non-adjacent di-caffeoylquinic acids [40]. 


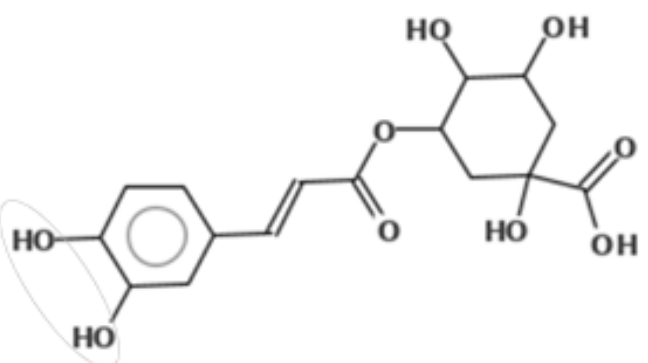

3-caffeoylquinic acid

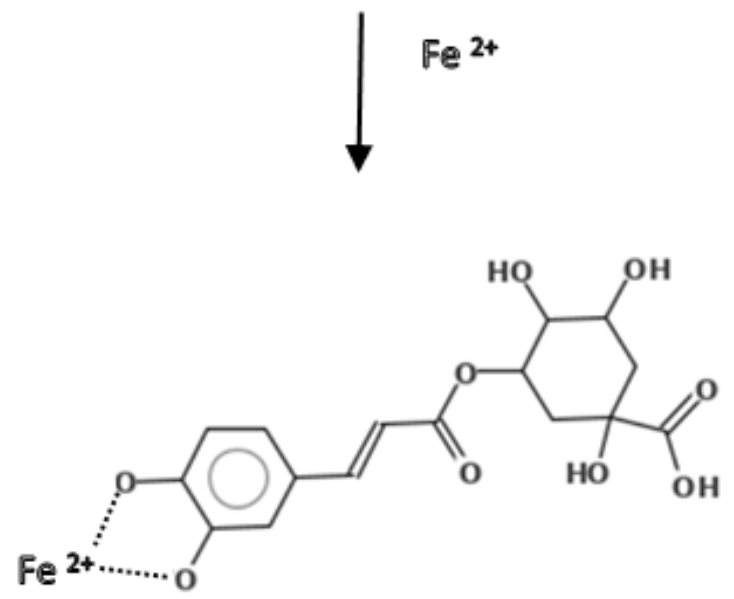

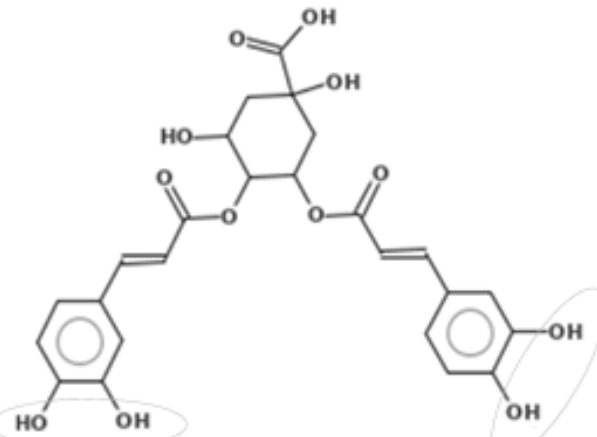

4,5-caffeoylquinic acid

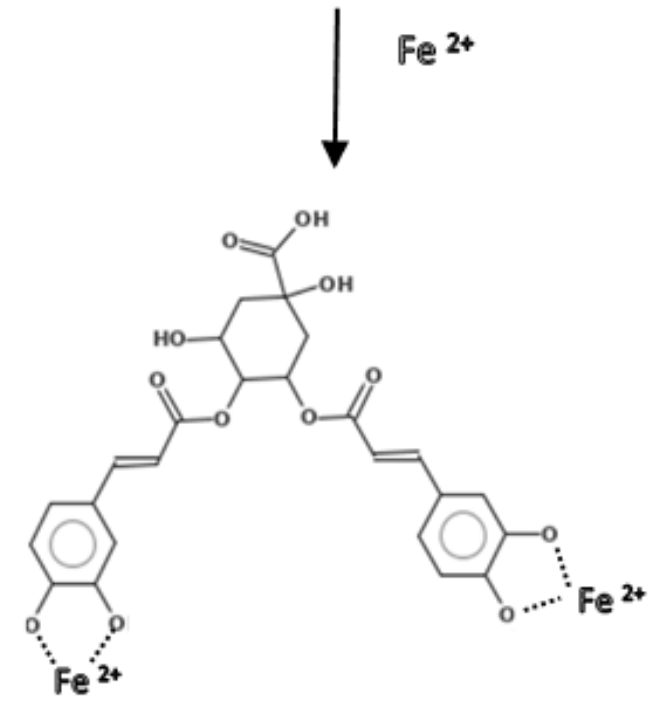

Figure 5. Structures of two caffeoylquinic acids found in the llex paraguariensis leaf infusion and the binding site of iron proposed, according to the literature $[36,39,40]$.

Although transition metals besides $\mathrm{Fe}^{+2}$, e.g. $\mathrm{Zn}^{+2}, \mathrm{Cu}^{+2}$, and $\mathrm{Mn}^{+2}$, could be complexed by compounds which have metal-chelating properties [41], the quantities of metal ions and phenolic compounds, and the differences in solubility of several foods and beverage sources of minerals could affect differently the complexation with transition metals [40,42,43]. Afsana and coauthors [42] showed an effect of ingesting tannic acid on the decrease of iron absorption, but not on the absorption of zinc, copper, and manganese. Borowska and coauthors [44] reported that the Aronia berries extract, as well as cyanidin 3-O- $\beta$-galactoside and quercetin, can bind $\mathrm{Zn}^{+2}$ and $\mathrm{Cu}^{+2}$, but only at $\mathrm{pH}$ 5.5. The lead (toxic metal) complexation by 5-CQA was shown in vitro in aqueous solution by jointly using UV-visible absorption spectroscopy and quantum chemical calculations [45]. Considering the biological importance of transition metals, when in suitable concentrations in the body, it should be investigated whether Ilex paraguariensis, as well as their caffeoylquinic acids, has an affinity for other transition metals.

In relation to the preliminary in vivo data, to our knowledge, no study in healthy subjects has been published on the potential of Ilex paraguariensis infusion to inhibit iron absorption after ingestion of a meal. Three healthy subjects ingested a meal enriched with non-haem iron $(11.4 \mathrm{mg}$ ) with $200 \mathrm{~mL}$ water (control) or llex paraguariensis infusion in a preliminary crossover trial. The measurement of the serum iron up to $4 \mathrm{~h}$ after intake clearly showed that the Ilex paraguariensis infusion promoted an expressive inhibition of the dietary iron absorption (Figure 4) by, in average, $81 \%$ AUC, $80 \% \Delta$ iron maximum, and $78 \%$ iron recovery at peak maximum (Table 3).

Considering the variable percentage iron recovery, our results with llex paraguariensis infusion (1.11\%) and water $(5.13 \%$; Table 3 ) were very similar to black tea in a study that evaluated the inhibition of non-haem iron absorption in 10 healthy volunteers (6 M and $4 \mathrm{~F}$ ) [46]. In that study, an iron-fortified bread consumed with water showed $4.46 \%$ iron recovery and $0.92 \%$ for black tea.

Non-haem iron is the mainly source of iron in the diet [47]. Therefore, plant food or infusions with a potential to reduce iron absorption at $50 \%$ or more in humans have been considered a potent iron absorption inhibitor [46], which might be interesting for iron overload treatment. 
Caffeoylquinic acids are bioactive compounds widely present in plants, which have also shown to be sources of minerals, including transition metals, such as iron $[14,48]$. Considering that an adult under normal condition needs to absorb only $10 \%$ of the usual dietary iron (10-20 mg/day), in which $2 / 3$ are obtained from plants, caffeoylquinic acids in plant food or beverages could favorably contribute to iron absorption modulation, without affecting iron homeostasis, given that human body does not have an efficient mechanism to excrete iron $[49,50]$. In the present study, the extraction of compounds from Ilex paraguariensis was optimized to enhance the iron-chelating activity of this plant.

It has been highlighted the iron-chelating proprieties of Camellia sinensis infusions (black tea and green tea), and the importance to investigate natural iron-chelating for chronic iron overload diseases [20,51]. In this context, we introduced the llex paraguariensis leaf infusion as a new and potential iron-chelating adjuvant.

\section{CONCLUSION}

The studied Ilex paraguariensis infusion, rich in phenolic compounds, promoted a complexation with iron in vitro, with probable involvement of caffeoylquinic acids, and it is suggested that a similar effect may occur in vivo, decreasing the iron absorption in healthy individuals. Therefore, our results showed an innovative research area for the llex paraguariensis infusion as a natural iron-chelating agent. Furthermore, we showed that the commonly used infusion time and water volume affected the extraction of phenolic compounds and the iron-chelating activity of Ilex paraguariensis infusion, which has a saturating effect at low total phenol content. Consequently, the Ilex paraguariensis infusion was highly stable at room temperature for the ironchelating activity. Based on these results, it is suggested that short-term and/or long-term studies should be carried out to investigate the in vivo iron chelating properties in humans with iron overload diseases.

Funding: This research was funded by Coordenação de Aperfeiçoamento de Pessoal de Nível Superior - Brazil (CAPES), grant number 001".

Conflicts of Interest: The authors declare no conflict of interest. The funders had no role in the design of the study; in the collection, analyses, or interpretation of data; in the writing of the manuscript, or in the decision to publish the results.

\section{REFERENCES}

1. Heck Cl, De Mejia EG. Yerba mate tea (Ilex paraguariensis): a comprehensive review on chemistry, health implications, and technological considerations. J Food Sci. 2007 Nov;72(9):R138-51. https://doi.org/10.1111/j.1750-3841.2007.00535.x.

2. Cardozo Junior EL, Morand C. Interest of mate (Ilex paraguariensis A. St.-Hil.) as a new natural functional food to preserve human cardiovascular health - A review. J Funct Foods. 2016 Mar;21:440-54. https://doi.org/10.1016/j.jff.2015.12.010.

3. Baeza G, Sarriá B, Bravo L, Mateos R. Polyphenol content, in vitro bioaccessibility and antioxidant capacity of widely consumed beverages. J Sci Food Agric. 2018 Mar;98(4):1397-406. https://doi.org/10.1002/jsfa.8607.

4. Gugliucci A. Antioxidant effects of Ilex paraguariensis: induction of decreased oxidability of human LDL in vivo. Biochem Biophys Res Commun.1996 Jul;224(2):338-44. https://doi.org/10.1006/bbrc.1996.1030.

5. Da Silva EL, Neiva TJC, Shirai M, Terao J, Abdalla DSP. Acute ingestion of yerba mate infusion (Ilex paraguariensis) inhibits plasma and lipoprotein oxidation. Food Res Int. 2008 Dec;41(10):973-9. https://doi.org/10.1016/j.foodres.2008.08.004.

6. De Morais EC, Stefanuto A, Klein GA, et al. Consumption of yerba mate (Ilex paraguariensis) improves serum lipid parameters in healthy dyslipidemic subjects and provides an additional LDL-Cholesterol reduction in individuals on statin therapy. J Agric Food Chem. 2009 Sep;57(18):8316-24. https://doi.org/10.1021/jf901660g.

7. Klein GA, Stefanuto A, Boaventura BC, et al. Mate tea (Ilex paraguariensis) improves glycemic and lipid profiles of type 2 diabetes and pre-diabetes individuals: a pilot study. J Am Coll Nutr. 2011 Oct;30(5):320-32. https://doi.org/10.1080/07315724.2011.10719975.

8. Panza VP, Brunetta HS, de Oliveira MV, Nunes EA, da Silva EL. Effect of mate tea (Ilex paraguariensis) on the expression of the leukocyte NADPH oxidase subunit p47 phox and on circulating inflammatory cytokines in healthy men: a pilot study. Int J Food Sci Nutr. 2019 Mar;70(2):212-21. https://doi:10.1080/09637486.2018.1486393.

9. Cahuê F, Nascimento JHM, Barcellos L, Salerno VP. Ilex paraguariensis, exercise and cardioprotection: a retrospective analysis. J Funct Foods. 2019 Feb;53:105-8. https://doi.org/10.1016/j.jff.2018.12.008.

10. Colpo AC, Rosa H, Lima ME, et al. Yerba mate (Ilex Paraguariensis St. Hill.)-based beverages: how successive extraction influences the extract composition and its capacity to chelate iron and scavenge free radicals. Food Chem. 2016 Oct;209:185-95. https://doi.org/10.1016/j.foodchem.2016.04.059. 
11. Hofer T, Marzetti E, Xu J, et al. Increased iron content and RNA oxidative damage in skeletal muscle with aging and disuse atrophy. Exp Gerontol. 2008 Jun;43(6):563-70. https://doi.org/10.1016/j.exger.2008.02.007.

12. Imam MU, Zhang S, Ma J, Wang H, Wang F. Antioxidants mediate both iron homeostasis and oxidative stress. Nutrients. 2017 Jun;9(7):1-19. https://doi.org/10.3390/nu9070671.

13. Jiao Y, Wilkinson IVJ, Di X, et al. Curcumin, a cancer chemopreventive and chemotherapeutic agent, is a biologically active iron chelator. Blood. 2009 Jan;113(2):462-9. https://doi.org/10.1182/blood-2008-05-155952.

14. Pagliosa CM, Vieira MA, Podestá R, et al. Methylxanthines, phenolic composition, and antioxidant activity of bark from residues from mate tree harvesting (Ilex paraguariensis A. St. Hil.). Food Chem. 2010 Sep;122(1):173-8. https://doi.org/10.1016/j.foodchem.2010.02.040.

15. Da Silveira TFF, Meinhart AD, Ballus CA, Godoy HT. The effect of the duration of infusion, temperature, and water volume on the rutin content in the preparation of mate tea beverages: An optimization study. Food Res Int. 2014 Jun;60:241-5. https://doi.org/10.1016/j.foodres.2013.09.024.

16. Gebara KS, Gasparotto-Junior A, Santiago PG, et al. Daily intake of chlorogenic acids from consumption of Maté (Ilex paraguariensis A.St.-Hil.) traditional beverages. J Agric Food Chem. 2017 Nov;65(46):10093-100. https://doi.org/10.1021/acs.jafc.7b04093.

17. Vieira MA, Maraschin M, Rovaris ÂA, et al. Occurrence of polycyclic aromatic hydrocarbons throughout the processing stages of erva-mate (llex paraguariensis). Food Addit Contam - Part A. 2010 Mar;27(6):776-82. https://doi.org/10.1080/19440041003587310.

18. Yatsu FKJ, Borghetti GS, Bassani VL. Technological characterization and stability of Ilex paraguariensis St. Hil. Aquifoliaceae (Maté) spray-dried powder. J Med Food. 2011 Mar;14(4):413-9. https://doi.org/10.1089/jmf.2010.0044.

19. Molin RF, Dartora N, Borges ACP, Gonçalves IL, Di Luccio M, Valduga AT. Total phenolic contents and antioxidant activity in oxidized leaves of mate (Ilex paraguariensis St. Hil). Brazilian Arch BiolTechnol. 2014 Nov;57(6):9971003. https://doi.org/10.1590/S1516-8913201402305.

20. Kaltwasser J, Werner E, Gottschalk R, et al. Clinical trial on the effect of regular tea drinking on iron accumulation in genetic haemochromatosis. Gut. 1998;43(5):699-704. https://doi.org/10.1136/gut.43.5.699.

21. Kim EY, Ham SK, Shigenaga MK, Han O. Bioactive dietary polyphenolic compounds reduce nonheme iron transport across human intestinal cell monolayers. J Nutr. 2008 Sep;138(9):1647-51. https://doi.org/10.1093/jn/138.9.1647.

22. Tyagi P, Kumar Y, Gupta D, Singh H, Kumar A. Therapeutic advancements in management of iron overload - A review. Int J Pharm Pharm Sci. 2015 Jan;7(8):43-52. ISSN-0975-1491.

23. Chadare FJ, Idohou R, Nago E, et al. Conventional and food-to-food fortification: an appraisal of past practices and lessons learned. Food Sci Nutr. 2019 Aug;7:2781-95. https://doi.org/10.1002/fsn3.1133.

24. Boado LS, Fretes RM, Brumovsky LA. Effects of Ilex paraguariensis polyphenols on magnesium absortion and iron bioavailability: Preliminary study. J Food Res. 2018;7(2):114-26. https://doi.org/10.5539/jfr.v7n2p114.

25. Astill C, Birch MR, Dacombe C, Humphrey PG, Martin PT. Factors affecting the caffeine and polyphenol contents of black and green tea infusions. J Agric Food Chem. 2001 Oct;49(11):5340-7. https://doi.org/10.1021/jf010759+.

26. Dinis LM, Madeira TCP, Almeida, V. Action of phenolic derivates [acetaminophen, salycilate, and 5-aminosalycilate] as inhibitors of membrane lipid peroxidation and as peroxylradical scavengers. Arch Biochem Biophys. 1994;315(1):161-9.

27. Singleton VL, Rossi JA. Colorimetry of total phenolics with phosphomolybdic-phosphotungstic acid reagents. Am J Enol Vitic. 1965;16:144-58.

28. Farah A, De Paulis T, Trugo LC, Martin, PR. Effect of roasting on the formation of chlorogenic acid lactones in coffee. J Agric Food Chem. 2005 Feb;53(5):1505-13. https://doi.org/10.1021/jf048701t.

29. Alves TL. Detecção de metabólitos do ácido clorogênico e metilxantinas em plasma e urina de indivíduos saudáveis após a ingestão de erva-mate (Ilex paraguariensis, A. St.-Hil.) [dissertation]. Florianópolis (SC) Brazil: Federal University of Santa Catarina; 2016. 114 p.

30. Srinivas N, Sandeep KS, Anusha Y, Devendra BN. In vitro cytotoxic evaluation and detoxification of monocrotaline (Mct) alkaloid: an in silico approach. Int Invent J Biochem Bioinforma. 2014 Mar;2(2):20-9.

31. AOAC. Official Methods of Analysis of the Association of Official Analytical Chemists. 20th ed. Gaithersburg: AOAC Ind; 2016.

32. Nishiyama MF, Costa MAF, Costa AM, et al. Chá verde brasileiro (Camellia sinensis var assamica): efeitos do tempo de infusão, acondicionamento da erva e forma de preparo sobre a eficiência de extração dos bioativos e sobre a estabilidade da bebida. Ciência e Tecnol Aliment. 2010 May;30(003582):191-6. https://doi.org/10.1590/S0101-20612010000500029. 
33. Okaru AO, Rullmann A, Farah A, De Mejia, EG, Stern MC, Lachenmeier DW. Comparative oesophageal cancer risk assessment of hot beverage consumption (coffee, mate and tea): The margin of exposure of PAH vs very hot temperatures. BMC Cancer. 2018 Mar;18(1):1-13. https://doi.org/10.1186/s12885-018-4060-z.

34. Vicente SJV, Queiroz YS, Gotlieb SLD, Torres EAFS. Stability of phenolic compounds and antioxidant capacity of regular and decaffeinated coffees. Brazilian Arch Biol Technol. 2014 Jan;57(1):110-8. https://doi.org/10.1590/S1516-89132014000100016.

35. Takenaka M, Nanayama K, Isobe S, Murata M. Changes in caffeic acid derivatives in sweet potato (Ipomoeabatatas L.) during cooking and processing. Biosci Biotechnol Biochem. 2006 May;70(1):172-7. https://doi.org/10.1271/bbb.70.172.

36. Kono Y, Kashine S, Yoneyama T, Sakamoto Y, Matsui Y, Shibata H. Iron chelation by chlorogenic acid as a natural antioxidant. Biosci Biotechnol Biochem. 1998;62(1):22-7. https://doi.org/10.1271/bbb.62.22.

37. Tuntipopipat S, Judprasong K, Zeder $\mathrm{C}$, et al. Chili, but not turmeric, inhibits iron absorption in young women from an iron-fortified composite meal. J Nutr. 2006 Dec;136(12):2970-4. https://doi.org/10.1093/jn/136.12.2970.

38. Filip R, López P, Giberti G, Coussio J, Ferraro G. Phenolic compounds in seven South American Ilex species. Fitoterapia. 2001 Nov;72(7):774-8. https://doi.org/10.1016/S0367-326X(01)00331-8.

39. Andjelković M, Van Camp J, De Meulenaer B, et al. Iron-chelation properties of phenolic acids bearing catechol and galloyl groups. Food Chem. 2006 Jul;98(1):23-31. https://doi.org/10.1016/j.foodchem.2005.05.044.

40. Li X, Li K, Xie H, et al. Antioxidant and cytoprotective effects of the Di-O-Caffeoylquinic acid family: the mechanism, structure-activity relationship, and conformational effect. Molecules. 2018 Jan;23(1):1-12. https://doi.org/10.3390/molecules23010222.

41. Dehariya R, Chandrakar J, Dubey S, Ojha K, Dixit AK. Scavenging and metal chelating potential of Carthamus tinctorius L. extracts. Curr Bot. 2020 May;11:43-50. https://doi.org/10.25081/cb.2020.v11.6009.

42. Afsana K, Shiga K, Ishizuka S, Hara H. Reducing effect of ingesting tannic acid on the absorption of iron, but not of zinc, copper and manganese by rats. Biosci Biotechnol Biochem. 2004;68(3):584-92. https://doi.org/10.1271/bbb.68.584.

43. Lobbes $\mathrm{H}$, Gladine $\mathrm{C}$, Mazur A, et al. Effect of procyanidin on dietary iron absorption in hereditary hemochromatosis and in dysmetabolic iron overload syndrome: a crossover double-blind randomized controlled trial. Clin Nutr. 2020 Jan;39(1):97-103. https://doi.org/10.1016/j.clnu.2019.02.012.

44. Borowska S, Tomczyk M, Strawa JW, Brzóska MM. Estimation of the chelating ability of an extract from Aronia melanocarpa L. Berries and its main polyphenolic ingredients towards ions of zinc and copper. Molecules. 2020 Mar;25(7):1-15. https://doi.org/10.3390/molecules25071507.

45. Cornard J, Lapouge C, Dangleterre L, Allet-Bodelot C. Complexation of lead(II) by chlorogenic acid: Experimental and theoretical study. J Phys Chem A. 2008 Nov;112(48):12475-84. https://doi.org/10.1021/jp805463p.

46. Hurrell RF, Reddy M, Cook JD. Inhibition of non-haem iron absorption in man by polyphenolic-containing beverages. Br J Nutr. 1999 Apr;81(4):289-95. https://doi.org/10.1017/S0007114599000537.

47. Cozzolino SMF. Ferro. In: Henriques GS, Cozzolino SMF, editors. Biodisponibilidade de nutrientes. Brasil: Manole; 2005. p 569-95.

48. De Moraes MR, Ryan SM, Godoy HT, et al. Phenolic compounds and metals in some edible annonaceae fruits. Biol Trace Elem Res. 2020 Oct;197:676-82. https://doi.org/10.1007/s12011-019-02005-w.

49. Anderson GJ, Frazer DM. Current understanding of iron homeostasis. Am J Clin Nutr. 2017 Dec;106(Suppl):1559S1566S. https://doi.org/10.3945/ajcn.117.155804.

50. Allen RP, Picchietti DL, Auerbach M, et al. Evidence-based and consensus clinical practice guidelines for the iron treatment of restless legs syndrome/Willis-Ekbom disease in adults and children: an IRLSSG task force report. Sleep Med. 2018 Jan;41:27-44. https://doi.org/10.1016/j.sleep.2017.11.1126.

51. Bordbar M, Pasalar M, Safaei S, et al. Complementary and alternative medicine use in thalassemia patients in Shiraz, southern Iran: a cross-sectional study. J Tradit Complement Med. 2018 Jan;8:141-6. https://doi.org/10.1016/j.jtcme.2017.05.002.

(C) 2021 by the authors. Submitted for possible open access publication under the terms and conditions of the Creative Commons Attribution (CC BY NC) license (https://creativecommons.org/licenses/by-nc/4.0/). 